\title{
Proteinase-activated receptor 4 stimulation-induced epithelial-mesenchymal transition in alveolar epithelial cells Seijitsu Ando ${ }^{1,2}$, Hitomi Otani ${ }^{1}$, Yasuhiro Yagi ${ }^{2}$, Kenzo Kawai ${ }^{3}$, Hiromasa Araki ${ }^{3}$, Shirou Fukuhara ${ }^{2}$ and Chiyoko Inagaki*1
}

\author{
Address: ${ }^{1}$ Department of Pharmacology, Kansai Medical University, 10-15, Fumizono-Cho, Moriguchi, Osaka 570-8506, Japan, ${ }^{2}$ The First \\ Department of Internal Medicine, Kansai Medical University, 10-15, Fumizono-Cho, Moriguchi, Osaka 570-8506, Japan and ${ }^{3}$ Fuso \\ Pharmaceutical Industries, Ltd., Joto-ku, Osaka 536-8523, Japan \\ Email: Seijitsu Ando - andos@takii.kmu.ac.jp; Hitomi Otani - otani@takii.kmu.ac.jp; Yasuhiro Yagi - yagiy@takii.kmu.ac.jp; Kenzo Kawai - k- \\ kawai@fuso-pharm.co.jp; Hiromasa Araki - h-araki@fuso-pharm.co.jp; Shirou Fukuhara - fukuhara@takii.kmu.ac.jp; \\ Chiyoko Inagaki* - inagaki@takii.kmu.ac.jp \\ * Corresponding author
}

Published: 16 April 2007

Respiratory Research 2007, 8:31 doi:10.1 |86/|465-992I-8-31
Received: 19 January 2007

Accepted: 16 April 2007

This article is available from: http://respiratory-research.com/content/8/I/3।

(C) 2007 Ando et al; licensee BioMed Central Ltd.

This is an Open Access article distributed under the terms of the Creative Commons Attribution License (http://creativecommons.org/licenses/by/2.0), which permits unrestricted use, distribution, and reproduction in any medium, provided the original work is properly cited.

\begin{abstract}
Background: Proteinase-activated receptors (PARs; PAR $_{1-4}$ ) that can be activated by serine proteinases such as thrombin and neutrophil catepsin $G$ are known to contribute to the pathogenesis of various pulmonary diseases including fibrosis. Among these PARs, especially PAR ${ }_{4}$, a newly identified subtype, is highly expressed in the lung. Here, we examined whether PAR 4 stimulation plays a role in the formation of fibrotic response in the lung, through alveolar epithelialmesenchymal transition (EMT) which contributes to the increase in myofibroblast population.
\end{abstract}

Methods: EMT was assessed by measuring the changes in each specific cell markers, E-cadherin for epithelial cell, $\alpha$-smooth muscle actin ( $\alpha$-SMA) for myofibroblast, using primary cultured mouse alveolar epithelial cells and human lung carcinoma-derived alveolar epithelial cell line (A549 cells).

Results: Stimulation of PAR with thrombin (I U/ml) or a synthetic PAR ${ }_{4}$ agonist peptide (AYPGKF$\left.\mathrm{NH}_{2}, 100 \mu \mathrm{M}\right)$ for $72 \mathrm{~h}$ induced morphological changes from cobblestone-like structure to elongated shape in primary cultured alveolar epithelial cells and A549 cells. In immunocytochemical analyses of these cells, such $\mathrm{PAR}_{4}$ stimulation decreased E-cadherin-like immunoreactivity and increased $\alpha$-SMA-like immunoreactivity, as observed with a typical EMT-inducer, tumor growth factor- $\beta$ (TGF- $\beta$ ). Western blot analyses of PAR $_{4}$-stimulated A549 cells also showed similar changes in expression of these EMT-related marker proteins. Such $\mathrm{PAR}_{4}$-mediated changes were attenuated by inhibitors of epidermal growth factor receptor (EGFR) kinase and Src. PAR $4^{-}$ mediated morphological changes in primary cultured alveolar epithelial cells were reduced in the presence of these inhibitors. $\mathrm{PAR}_{4}$ stimulation increased tyrosine phosphorylated EGFR or tyrosine phosphorylated Src level in A549 cells, and the former response being inhibited by Src inhibitor.

Conclusion: $\mathrm{PAR}_{4}$ stimulation of alveolar epithelial cells induced epithelial-mesenchymal transition (EMT) as monitored by cell shapes, and epithelial or myofibroblast marker at least partly through EGFR transactivation via receptor-linked Src activation. 


\section{Background}

Proteinase-activated receptors (PARs) are newly identified G-protein-coupled receptors that can be activated by serine proteinases such as thrombin, trypsin, mast cell tryptase and neutrophil cathepsin $G[1,2]$. These proteinases cleave the extracellular amino terminal domain of PARs to create a new $\mathrm{NH}_{2}$ terminal sequence, which functions as a tethered ligand to initiate each receptor-coupled cell signaling. To date, four PARs have been cloned; $\mathrm{PAR}_{1}, \mathrm{PAR}_{3}$ and $\mathrm{PAR}_{4}$ are preferentially activated by thrombin, while $\mathrm{PAR}_{2}$ are selectively activated by trypsin [2]. In the respiratory system, $\mathrm{PAR}_{1}, \mathrm{PAR}_{2}$ and $\mathrm{PAR}_{4}$ are expressed at different levels depending on the tissues or the cell types (epithelium, endothelium, tracheal smooth muscle and blood vessel), and reportedly modulate cytoskeletal structure and further contribute to the progression of various airway and lung disorders including inflammation and fibrosis [2-4]. For example, in systemic sclerosis patients with pulmonary fibrosis or idiopathic pulmonary fibrosis (IPF) patients, concentrations of thrombin and/or cathepsin $G$ in bronchoalveolar lavage fluid are much higher than those in healthy controls $[5,6]$. Therefore, thrombin receptors such as $\mathrm{PAR}_{1}$ and/or $\mathrm{PAR}_{4}$ in lung are thought to contribute to the pathogenesis of lung fibrosis. Indeed, Howell et al [3] demonstrated that bleomycin-induced fibrotic responses such as collagen accumulation and increases in profibrotic mediator levels were attenuated by $\mathrm{PAR}_{1}$-knockout, suggesting the involvement of $\mathrm{PAR}_{1}$ signal in the pathogenic mechanisms. However, contribution of another thrombin receptor, $\mathrm{PAR}_{4}$, has not been examined. In our recent study, $\mathrm{PAR}_{4}$ (mRNA/protein) has been demonstrated to be highly expressed in primary cultured mouse alveolar epithelial cells [7]. This enabled us to test the involvement of $\mathrm{PAR}_{4}$ stimulation in pathogenetic mechanisms of fibrosis in vitro.

Pulmonary fibrosis is a final common endpoint pathomechanism in various lung diseases including acute respiratory distress syndrome (ARDS) [8]. The process is characterized by multiple phenomena such as epithelial activation and damage, an excessive extracellular matrix deposition and a substantial increase in the number of fibroblasts/myofibroblasts [9], transforming growth factor- $\beta$ (TGF- $\beta$ ), interleukin- 4 and tumor necrosis factor- $\alpha$ being known as inducers of such fibrotic responses $[8,9]$. Recently, phenotypic transition of epithelial cell to mesenchymal cell (epithelial-mesenchymal transition; EMT) has received attention as an important mechanism of progressive increase in the number of myofibroblasts in various fibrotic tissues including kidney and lung [10-12]. Typical alveolar epithelia form a cobblestone-like sheet structure that tightly adhering to neighboring cells or various basal substrates, and play an active role in protecting lung from injury and infection [13]. Under persistent lung pathogenic insults, integrity and characteristics of alveolar epithelium are disturbed and rearranged to induce morphological or physiological alterations, for example, a loss of cell-cell contact, apoptosis and proliferation. Further, parts of epithelial cells are phenotypically changed to different types of cells like mesenchymal cell, i.e., EMT $[9,12]$. During EMT, the epithelial cells lose their characteristic morphology through a various intermediate stages like a loss of epithelial adhesion molecules such as E-cadherin (a specific epithelial marker) and secretion of matrix metalloproteinase (MMP). Finally, cells are converted to a mesenchymal phenotype and acquire myofibloblast morphology characterized by an elongated cell shape and de novo expression of $\alpha$-smooth muscle actin ( $\alpha$-SMA, a hallmark of myofibroblast). In several different studies, not only growth factor such as TGF- $\beta$, epidermal growth factor (EGF) and interleukin-1 but also some drugs (cyclosporine A and angiotensin $\mathrm{ll}$ ) have been shown to induce EMT of tubular and alveolar epithelial cells, thereby facilitating the progression of renal and lung fibrosis $[8,10,14-16]$.

In the present study, we examined whether stimulation of $\mathrm{PAR}_{4}$ which is known to be involved in the long-scale cellular responses [17] modulates epithelial morphology through EMT using primary cultured mouse alveolar epithelial cells and a human lung carcinoma-derived alveolar epithelial cell line (A549 cells). Possible mechanisms of the $\mathrm{PAR}_{4}$ 's effects were also analyzed with respect to the involvement of EGF receptor (EGFR) signaling, since this receptor is reportedly transactivated by various extracellular stimuli such as $\mathrm{G}$ protein-coupled receptors including PARs [18-20].

\section{Methods \\ Materials}

An agonist peptide for $\mathrm{PAR}_{4}$ (AYPGKF-NH $\mathrm{H}_{2}$ ), and an inactive reverse sequence peptide (FKGPYA- $\mathrm{NH}_{2}$ ) were synthesized by Fuso Pharmaceutical Industries, LTD., Research and Development Center (Osaka, Japan). Thrombin and monoclonal anti- $\alpha$-smooth muscle actin $(\alpha-S M A)$ antibody (Fluorescein isothiocyanate (FITC) conjugated purified mouse immunoglobulin) were purchased from Sigma chemicals (St. Louis, MO, USA). Joklik's modification Eagle's medium (JMEM), Dulbecco's modification Eagle's media (DMEM) and fetal calf serum (FCS) were from Gibco BRL Life Technologies (Grand Island, NY, USA); human TGF- $\beta 1$ was from Peprotech EC (Margravine Rode, London, UK); antibodies against Ecadherin, GAPDH and phospho-EGFR (specific for Tyr1173) were from Santa Cruz Biotechnology, Inc., (Santa Cruz, CA, USA); anti-Src and anti-phospho-Src (specific for Tyr416) antibodies were from Cell Signaling Technology, INC (Danvers, MA, USA); 4-Amino-5-(4chlorophenyl)-7-(t-butyl) pyrazolo [3,4-d pyrimidine (PP2) and 4-(3-Chloroanilino-6,7-dimethoxyquinazo- 
line (AG1478) were from BIOMOL International, L.P., (Matford court, UK); rhodamine red-conjugated goat anti-rabbit IgG was from Jakson Immunoresearch Laboratories, (West Grove, PA, USA); peroxidase-conjugated goat anti-rabbit or anti-mouse immnogloblin was from Cappel, ICN Pharmaceutical, Inc., (Aurora, OH, USA) or Zymed Laboratories Inc., (South San Francisco, CA, USA), respectively; ECL (enhanced chemiluminescence) kit was from NEN Life Science Product (Boston, MA, USA); and SCH-79797 dihydrochloride [(N³-Cyclopropyl-7-[[4-(1methylethyl)phenyl]methyl]-7H-pyrrolo [3,2-f]quinazoline-1,3-diamine dihydrochloride was from Tocris Cookson Ltd. (Bristol, BS11 9XJ, UK). All other chemicals were purchased from Wako Pure Chemical (Osaka, Japan) and of the highest purity available.

\section{Preparation of primary cultured alveolar epithelial cells}

All animals were handled in accordance with the "Rules of Animal Experimentation Committee, Kansai Medical University".

Healthy C57BL/6J mice (20-25 g) were anesthetized with intraperitoneal injection of pentobarbital $(1.5 \mathrm{mg} / 10 \mathrm{~g}$ body weight). Primary cell culture was accomplished using protocol described previously with a slight modification [21]. Briefly, the pulmonary vessel was perfused via the right cardiac ventricle with saline. The trachea was cannulated with 3 Fr tubing, and the lung was filled with 1-2 $\mathrm{ml}$ of JMEM containing $0.1 \%$ dispase (Godo-shusei, Tokyo, Japan) and $0.45 \mathrm{ml}$ of low-melting-point agarose. The lung was then placed in ice-cold JMEM for $2 \mathrm{~min}$ to harden the agarose and incubated in $2 \mathrm{ml}$ of the dispase solution for $20 \mathrm{~min}$ at room temperature. The lung was teased from the airways and minced in DMEM supplemented with penicillin (100 units $/ \mathrm{ml})$, streptomycin (100 $\mu \mathrm{g} / \mathrm{ml})$ and amphotericin B $(0.75 \mu \mathrm{g} / \mathrm{ml})$. The minced lung tissues were filtered successively through $133-, 42-$, and $22-\mu \mathrm{m}$ nylon mesh, and centrifuged at $130 \mathrm{~g}$ for 8 min. The resulting pellets were dispersed with DMEM supplemented with $10 \%$ FCS and then plated on a petri dish for $4 \mathrm{~h}$ to remove mesenchymal cells and the floating cells (non adherent cells) were plated on fibronectin (Chemiconez-International, Temecula, CA, USA)-coated circular glass coverslips placed in the plastic dishes at density of $20000 /$ dish. The viability of the isolated cells was checked by trypan-blue exclusion and was found to be greater than $98 \%$. Cells were maintained in DMEM supplemented with $10 \%$ fetal calf serum at $37^{\circ} \mathrm{C}$ in $5 \% \mathrm{CO}_{2}$ and $95 \%$ air. On the day 7 of culture, cells were immunocytochemically characterized using antibodies against pan-cytokeratin (which recognize cytokelatin 1-8, 10, 14-16, 19) (Nichirei Bioscience, Tokyo Japan) and vimentin (Dako, Carpinteria, CA, USA) as respective markers for epithelial cell and fibroblast. The majority of the cultured cells were epithelial cells with a uniform cobblestone pattern [21].
The contamination of fibroblasts was below $10 \%$. Macrophages or lymphocytes were not detected on the immnocytochemical analyses using antibodies against respective markers (Mac1 and CD45). Such cultures were subjected to experiments.

\section{Cell culture of A549 cells}

A549 cells (human lung carcinoma-derived alveolar epithelial cell line) were cultured in DMEM supplemented with penicillin $(100$ units $/ \mathrm{ml})$, streptomycin $(100 \mu \mathrm{g} / \mathrm{ml})$, amphotericin B $(0.75 \mu \mathrm{g} / \mathrm{ml})$ and $10 \%$ FCS at $37^{\circ} \mathrm{C}$ in 5 $\% \mathrm{CO}_{2}$ and $95 \%$ air. A549 cells were grown to $90 \%$ confluence in $10 \mathrm{~cm}$ plastic culture dishes and harvested by exposure to $0.05 \%$ trypsin and $0.02 \%$ EDTA followed by centrifugation at $90 \mathrm{~g}$ for $1 \mathrm{~min}$. The resulting pellets were resuspended in DMEM solution with the supplements and plated on the culture dishes for Western blotting analyses. After incubation at $37^{\circ} \mathrm{C}$ for 3 days to achieve $70-$ $90 \%$ confluent monolayer, the cells were incubated in DMEM with or without $1 \%$ FCS depending on experimental protocol.

\section{Immunocytochemistry in primary cultured alveolar epithelial cells and A549 cells}

Primary cultured alveolar epithelial cells grown on coverslips glass incubated with DMEM containing $1 \%$ FCS were stimulated with or without thrombin, AYPGKF- $\mathrm{NH}_{2}$ and TGF- $\beta$ for $72 \mathrm{~h}$ at $37^{\circ} \mathrm{C}$. The cells were fixed for $5 \mathrm{~min}$ with $1 \%$ paraformaldehyde in a phosphate-buffered solution (PBS) containing $136.9 \mathrm{mM} \mathrm{NaCl}, 2.1 \mathrm{mM} \mathrm{KCl}, 3.2$ $\mathrm{mM} \mathrm{Na}_{2} \mathrm{HPO}_{4}$ and $1.5 \mathrm{mM} \mathrm{KH}_{2} \mathrm{PO}_{4}$, $\mathrm{PH} 7.4$, and were washed twice with PBS. Fixed cells were permeated with 1 $\%$ Triton X-100 for $5 \mathrm{~min}$, and were washed twice with PBS solution. The cells were incubated with monoclonal antibody against E-cadherin in PBS containing $2 \mathrm{mg} / \mathrm{ml}$ bovine serum albumin (BSA) for $2 \mathrm{~h}$ at room temperature. The cells were then incubated with FITC-conjugated monoclonal antibody against $\alpha$-SMA and rhodamin red-conjugated goat anti-rabbit IgG and for $1 \mathrm{~h}$ at room temperature. On the other hand, after incubation with Ecadherin, A549 cells were incubated with monoclonal antibody against $\alpha$-SMA (Nichirei Bioscience, Tokyo Japan) for $1 \mathrm{~h}$ at room temperature. Then, the cells were incubated with FITC-conjugated goat anti-mouse IgG and rhodamin red-conjugated goat anti-rabbit IgG and for $1 \mathrm{~h}$ at room temperature. Coverslips with the cells were mounted on a slide and visualized using confocal laser microscopy system (LSM 510-META; Carl Zeiss, Iena, Germany) with a water immersion objective lens for high resolution; 8 frames per slide were captured. Aperture, gain and black level for image acquisition were maintained at a constant level. 


\section{Prepareation of cell lysates}

A549 cells were stimulated with test drugs in DMEM in the presence (for E-cadherin and $\alpha$-SMA detection) or absence (for pEGFR and pSrc detection) of $1 \%$ FCS for the indicated periods followed by harvest. The cells were lysed at $4{ }^{\circ} \mathrm{C}$ in the two kinds of cold lysis buffer. Triton buffer containing $30 \mathrm{mM}$ HEPES (pH 7.1), $100 \mathrm{mM} \mathrm{NaCl}, 1 \mathrm{mM}$ EGTA, 20 mM NaF, 1 \% Triton X-100, 1 mM phenylmethylsulphonylfluoride (PMSF) and $20 \mu \mathrm{l} / \mathrm{ml}$ protease inhibitor cocktail (Roche Diagnostics GmbH, Mannheim, Germany) were used for detection of E-cadherin and $\alpha$ SMA. RIPA (radio immunoprecipitation assay) buffer ( $\mathrm{pH}$ 7.4) containing $100 \mathrm{mM}$ HEPES, $300 \mathrm{mM} \mathrm{NaCl}, 2 \mathrm{mM}$ EDTA, 2 \% Nonidet P40, 1 \% sodium deoxycholate, $0.2 \%$ sodium lauryl sulfate (SDS), $3 \mathrm{mM} \mathrm{MgSO} 4,200 \mathrm{U} / \mathrm{ml}$ aprotinin, $20 \mu \mathrm{g} / \mathrm{ml}$ leupeptin, $1 \mathrm{mM} \mathrm{PMSF}, 100 \mathrm{mM} \mathrm{NaF}$,

\section{Control}

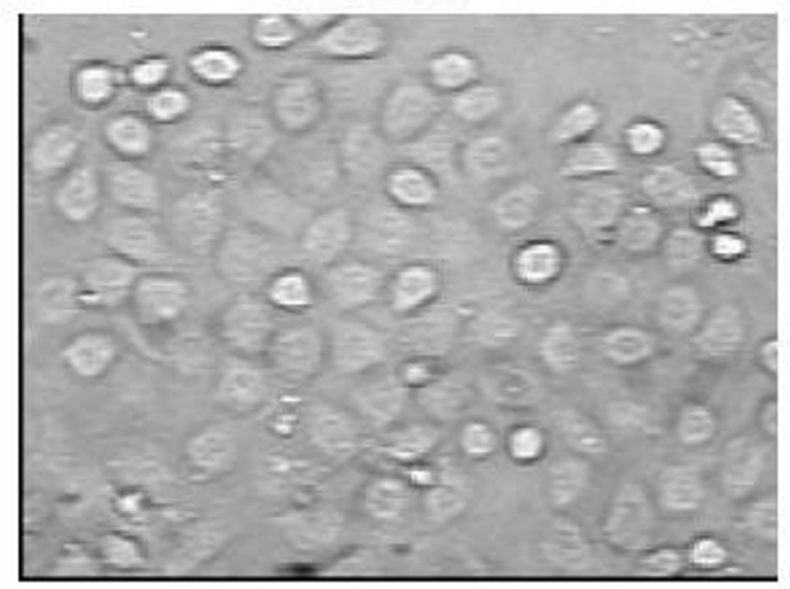

\section{AYPGKF $100 \mu \mathrm{M}$}

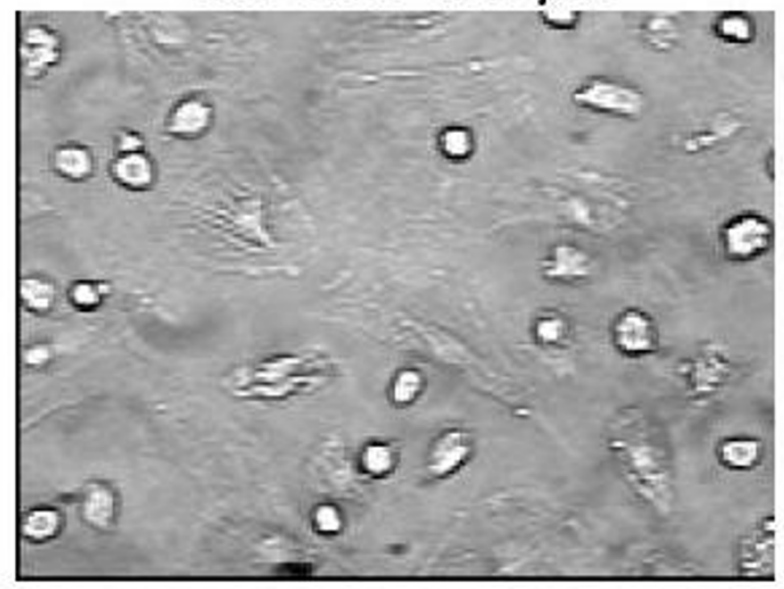

$10 \mathrm{mM}$ orthovanadate and $20 \mu \mathrm{l} / \mathrm{ml}$ protease inhibitor cocktail were used for detection of EGFR or Src phosphorylation. Both lysates obtained with each method were centrifuged $9000 \mathrm{~g}$ for $5 \mathrm{~min}$. The supernatants were mixed with a SDS-Laemmli sample buffer and boiled for $2 \mathrm{~min}$. Protein concentrations of the samples were measured using the Bio-Rad protein assay (Bio-Rad Laboratories, Hercules, CA, USA).

\section{Western blot analysis}

Equal amounts of samples ( $20 \mu \mathrm{g} /$ lane $)$ were separated on $7.5 \%$ SDS-polyacrylamide gel electrophoresis and transferred to an immobilon P membrane (Millipore Corporation, Bedford, MA, USA) using an electroblotting apparatus. The membrane was blocked with $5 \%$ non-fat milk or $1 \%$ BSA (for phosphorylated antibody) in Tris-

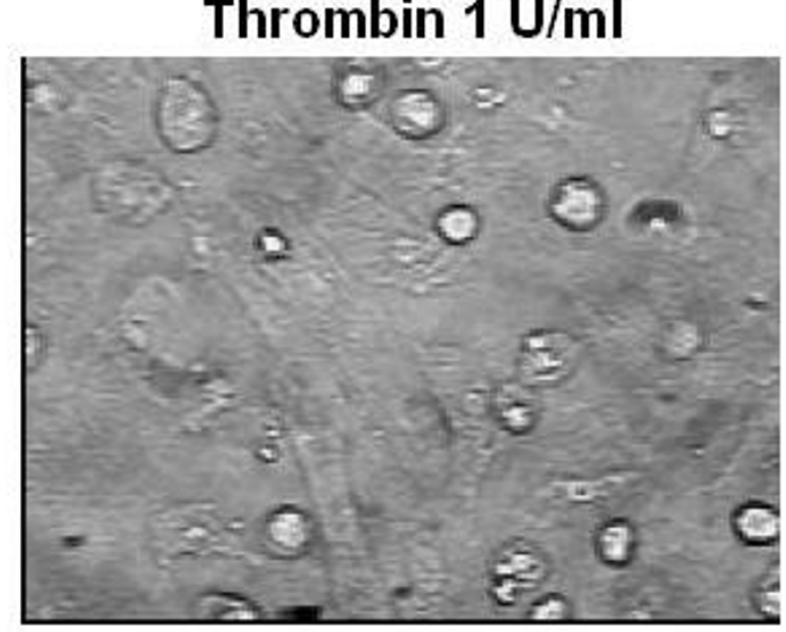

TGF $\beta 5 \mathrm{ng} / \mathrm{ml}$

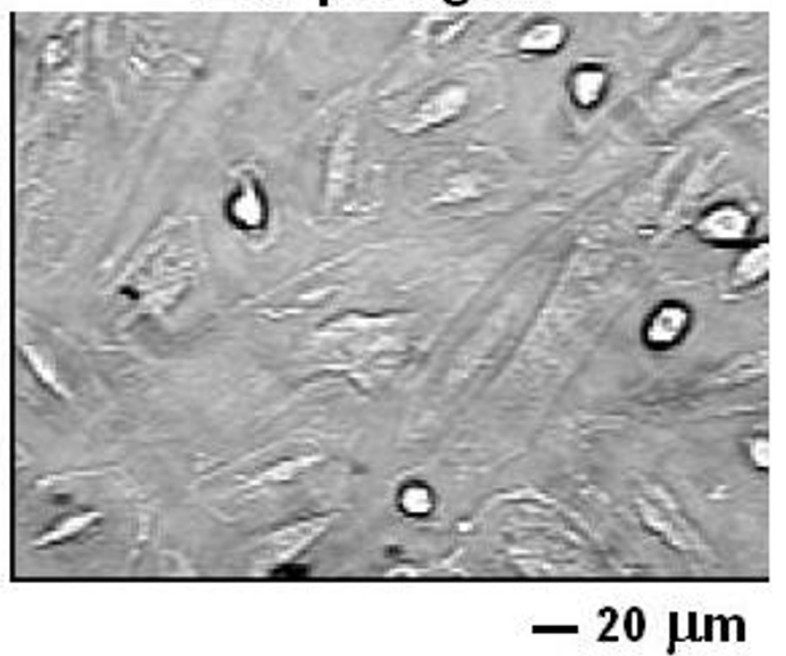

\section{Figure I}

Typical phase contrast images of primary cultured mouse alveolar epithelial cells. Epithelial cells were treated for

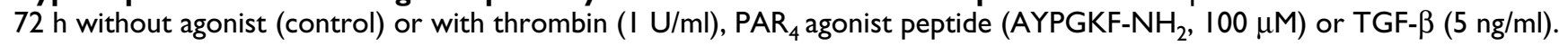



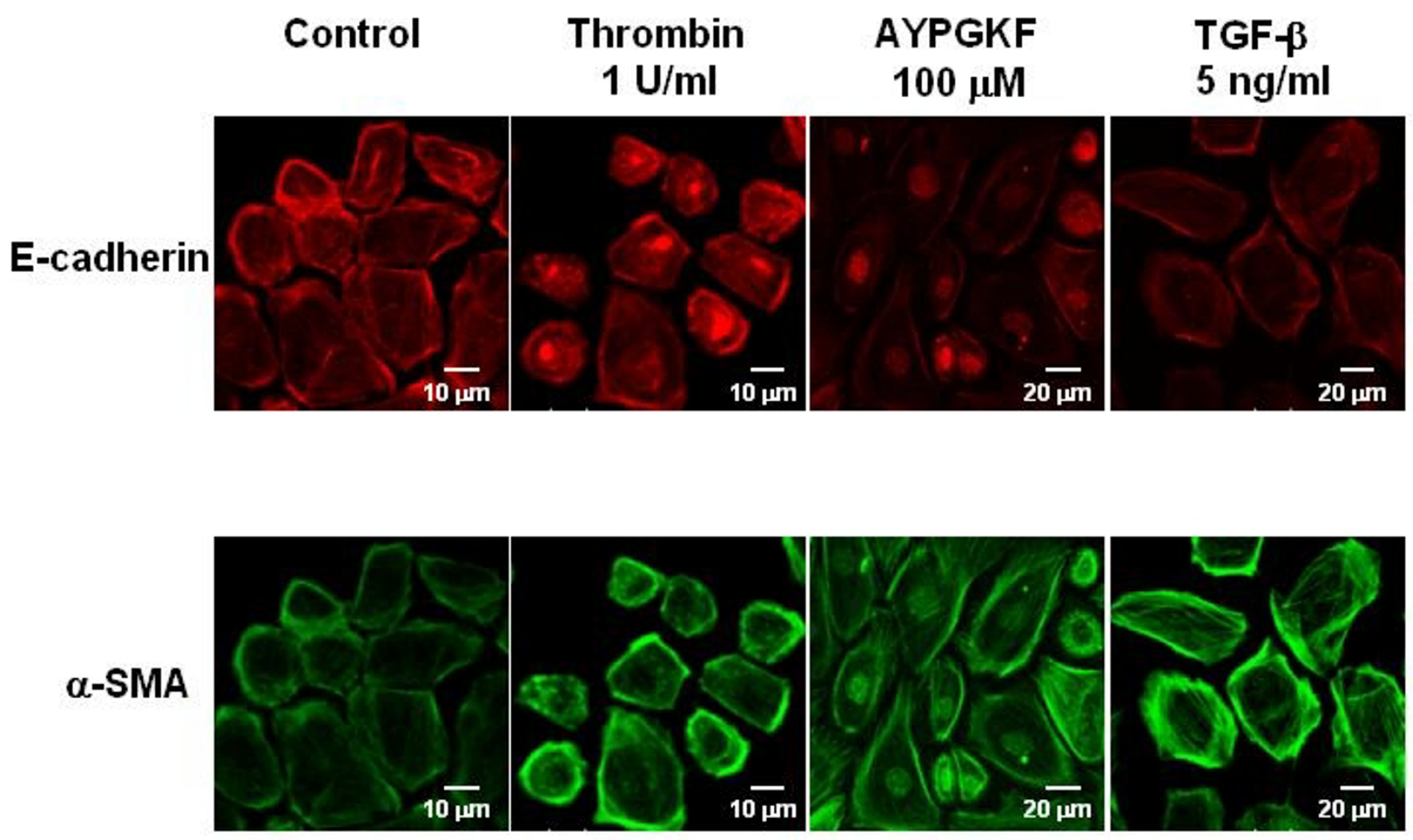

\section{Figure 2}

Phenotypic changes in primary cultured alveolar epithelial cells stimulated with PAR $_{4}$ agonists or TGF- $\beta$. Immunofluorescence images for a specific marker for epithelial cell (E-cadherin; rhodamine red, upper panel) or myofibroblast ( $\alpha$-SMA; FITC green, lower panel) captured with confocal lasar microscopy. Cells were treated with or without (control) various agonists (thrombin, AYPGKF-NH ${ }_{2}$ or TGF- $\beta$ ) for $72 \mathrm{~h}$, and stained for E-cadherin or $\alpha$-SMA using specific antibodies as described in Method section.

buffered saline (TBS; $50 \mathrm{mM}$ Tris and $150 \mathrm{mM} \mathrm{NaCl}, \mathrm{pH}$ 7.5) for $1 \mathrm{~h}$ at room temperature. The membrane was incubated with each primary antibody overnight at $4^{\circ} \mathrm{C}$. The membrane was then washed and incubated for with peroxidase-conjugated goat anti-rabbit or anti-mouse immunogloblin for $1 \mathrm{~h}$ at room temperature. The membrane was visualized by the enhanced chemiluminescence method. To confirm equal loading, the same membranes were stripped by incubating in a solution containing 100 mM 2-mercaptoethanol, $2 \%$ SDS and $62.5 \mathrm{mM}$ Tris- $\mathrm{HCl}$ $(\mathrm{pH} 6.8)$ for $1 \mathrm{~h}$ at $50^{\circ} \mathrm{C}$, then blotted with the antiGAPDH, anti-Src or anti-EGFR antibody.

The signal intensities were measured with a densitometer (DMU-33C; Advantec Digital Densitol, Tokyo, Japan).

\section{Statistical analysis}

Statistical analyses were performed by ANOVA and Bonferroni's test. When only two groups were compared, Student's t-test was used for statistical analysis. The differences between mean values with $P$ values less than 0.05 were considered significant.

\section{Results}

\section{Morphological changes induced by $P_{4} R_{4}$ agonists}

Figure 1 shows the typical morphological images of primary cultured alveolar epithelial cells assessed by phase contrast microscopy. Control cells formed monolayer in which individual cells displayed typical cobblestone-like shape and were tightly attached to each other. In contrast, after exposure to thrombin $(1 \mathrm{U} / \mathrm{ml})$ or a $\mathrm{PAR}_{4}$ agonist peptide (AYPGKF-NH $\mathrm{NH}_{2} 100 \mu \mathrm{M}$ ) for $72 \mathrm{~h}$, many cells showed an elongated shape and lost cell-cell contact. When the cells were treated with TGF- $\beta(5 \mathrm{ng} / \mathrm{ml})$, a potent EMT inducer $[8,10,22]$, such a morphological change was obvious, showing an extremely elongated shape like fibroblasts. $\mathrm{PAR}_{4}$ stimulation of alveolar epithelial cells thus appeared to induce phenotypic changes to mesenchymal-like cells. 
Control

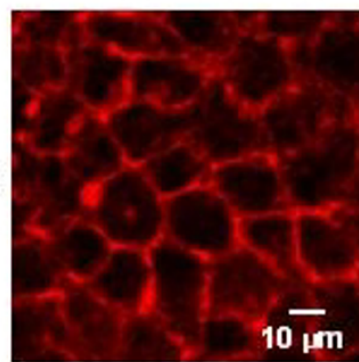

Thrombin $1 \mathrm{U} / \mathrm{ml}$

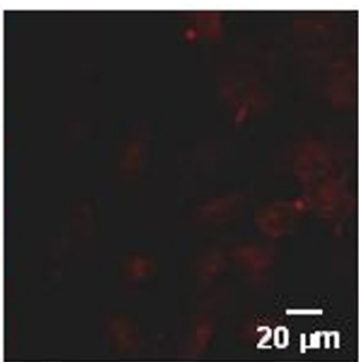

\section{AYPGKF $100 \mu \mathrm{M}$}

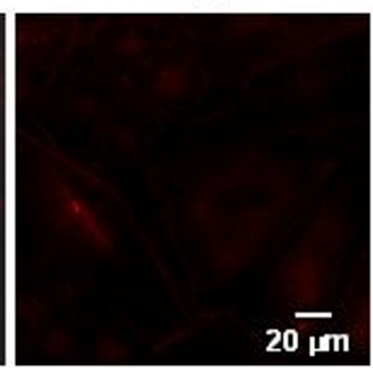

TGF- $\beta$ $5 \mathrm{ng} / \mathrm{ml}$

\section{E-cadherin}
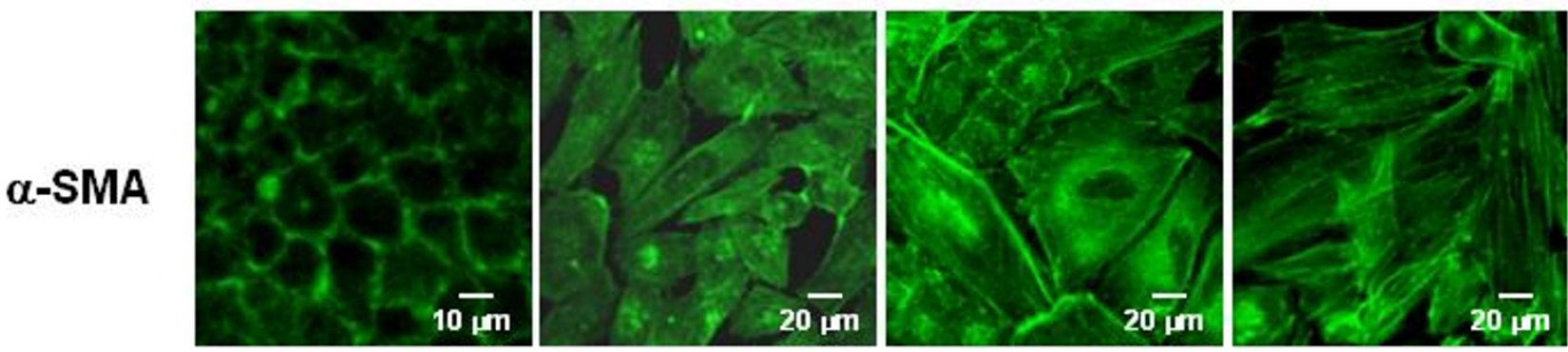

Figure 3

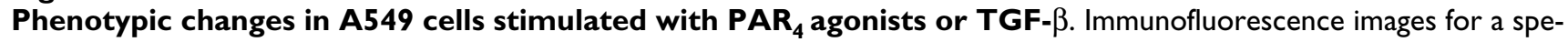
cific marker for epithelial cell (E-cadherin; rhodamine red, upper panel) or myofibroblast ( $\alpha$-SMA; FITC green, lower panel) captured with confocal lasar microscopy. Cells were treated with or without (control) various agonists (thrombin, AYPGKF$\mathrm{NH}_{2}$ or TGF- $\beta$ ) for $72 \mathrm{~h}$, and stained for E-cadherin or $\alpha$-SMA using specific antibodies as described in Method section.

\section{Changes in cell structure induced by $\mathbf{P A R}_{4}$ stimulation}

To address whether $\mathrm{PAR}_{4}$ stimulation induces EMT in the primary cultured alveolar epithelial cells, changes in expression pattern of epithelial or myofibroblast marker was immunocytochemically analyzed. Figure 2 shows a representative immunofluorescence image of expression of E-cadherin or $\alpha$-SMA, a typical marker of epithelial cell or myofibroblast, respectively. After $72 \mathrm{~h}$ exposure of the cells to either of $\mathrm{PAR}_{4}$ agonists, E-cadherin expression was significantly decreased concomitantly with reduced cellcell contact and loss of epithelial morphology. In contrast, strong expression of $\alpha$-SMA-positive microfilaments became clearly observed in the cytoplasmic peripheral area by the same treatments as compared with non-evident expression in control without stimulation. TGF- $\beta$ ( 5 $\mathrm{ng} / \mathrm{ml}, 72 \mathrm{~h}$ ) used as a typical EMT inducer showed a marked decrease or increase in expression of E-cadherin or $\alpha$-SMA, respectively. Such EMT responses were also observed in alveolar epithelial cell line (A549 cells) stimulated with $\mathrm{PAR}_{4}$ agonists and TGF- $\beta(5 \mathrm{ng} / \mathrm{ml})$ for $72 \mathrm{~h}$ (Fig. 3). In the next experiment, such immunocytochemi- cal changes in E-cadherin and $\alpha$-SMA expression was substantiated by Western blot analyses using A549 cells.

As shown in Figure 4A, treatment of A549 cells with thrombin ( 1 and $5 \mathrm{U} / \mathrm{ml}, 96 \mathrm{~h}$ ) decreased the amount of immunoreactive E-cadherin (molecular mass, $135 \mathrm{kD}$ ), and increased $\alpha$-SMA (molecular mass, $42 \mathrm{kD}$ ), compared with time-matched control (no treatment). A similar response to AYPGKF-NH $\mathrm{NH}_{2}(100 \mu \mathrm{M}, 96 \mathrm{~h})$, but not to a FKGPYA- $\mathrm{NH}_{2}\left(\mathrm{PAR}_{4}\right.$-inactive reverse sequence peptide, $100 \mu \mathrm{M}$ ), was also observed, suggesting the response to agonist peptide due to specific $\mathrm{PAR}_{4}$ stimulation (Figure $4 \mathrm{~B})$. Figure $4 \mathrm{C}$ and $4 \mathrm{D}$ show the pooled data obtained from 4-12 preparations. $\mathrm{PAR}_{4}$-mediated changes in expression level of each marker protein (decreases in Ecadherin or increases in $\alpha$-SMA) were quantitated by the densitometric analyses. Reverse sequence peptide (FKGPYA- $\mathrm{NH}_{2}$, inactive form) at the same concentration (100 $\mu \mathrm{M}$ ) did not show significant changes in the expressions of both marker proteins. 

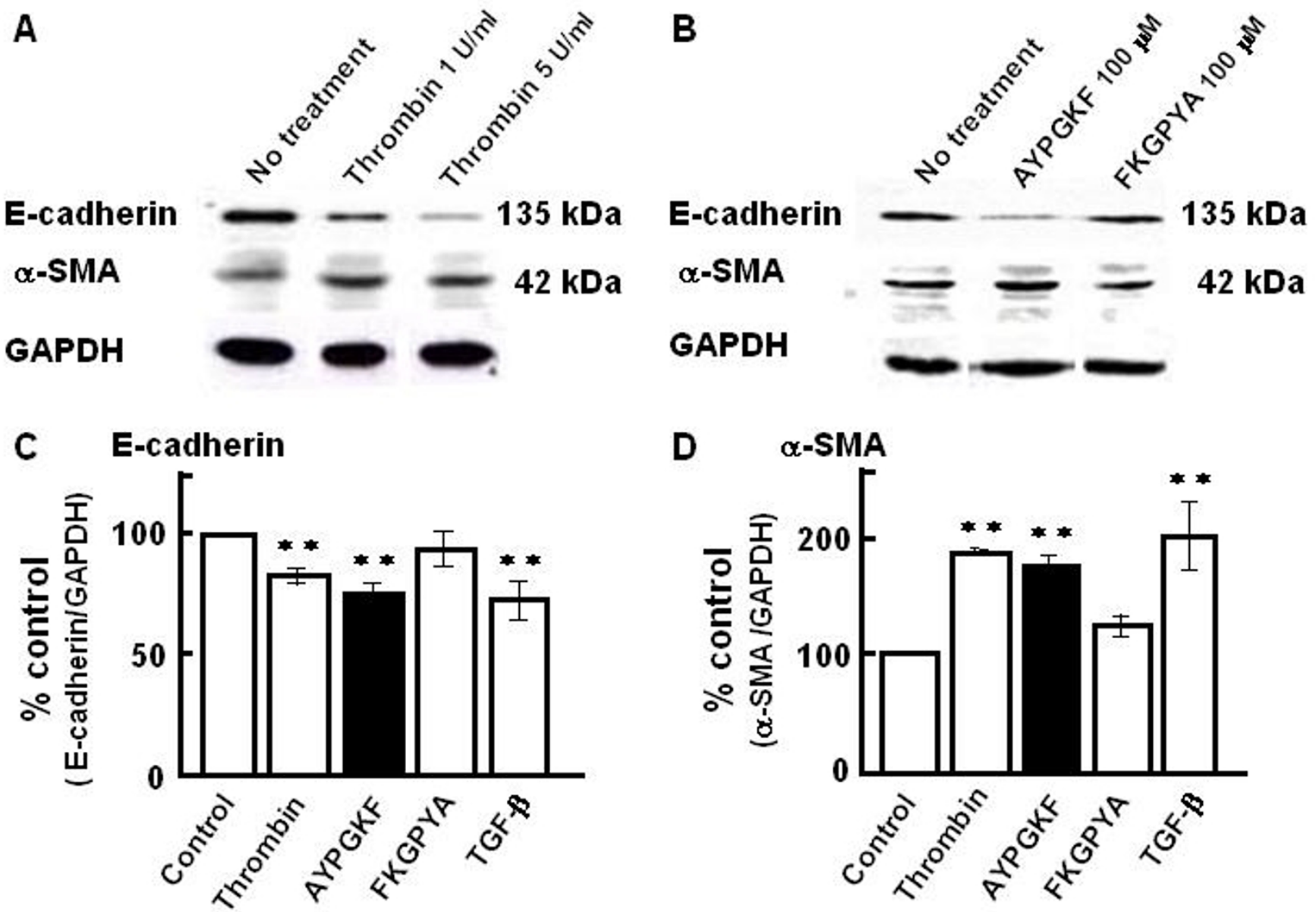

Figure 4

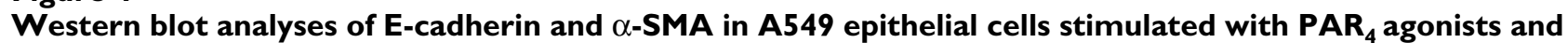
TGF- $\beta$. (A, B) Representative Western blots of E-cadherin and $\alpha$-SMA in A549 cells treated for $96 \mathrm{~h}$ with thrombin (A; I or 5 $\mathrm{U} / \mathrm{ml}$ ) or synthetic peptides (B; AYPGKF-NH $\mathrm{NH}_{2}$ or FKGPYA-NH $\mathrm{N}_{2} ; \mathrm{I} 00 \mu \mathrm{M}$ ). (C, D) Summarized densitometric data. Effects of PAR $_{4}$ agonists (thrombin; I U/ml and AYPGKF-NH $\left.{ }_{2} ; 100 \mu M\right)$, FKGPYA-NH $H_{2}(100 \mu M)$ or TGF- $\beta$ (5 ng/ml) on the expressions of E-cadherin (C) and $\alpha$-SMA (D). Results are based on densitometric analyses of the ratio of each marker protein to GAPDH (as internal standard). Each bar represents the mean \pm S.E.M. from 4-12 preparations. **P $<0.01$ compared with the control.

Thrombin-induced changes in each marker protein were not significantly affected by the $\mathrm{PAR}_{1}$-selective antagonist (SCH-79797, $300 \mathrm{nM}$ ) (E-cadherin; $78.3 \pm 3.2 \%$ or 75.6 $\pm 4.0 \%$ of untreated group, $\alpha-S M A ; 211.4 \pm 23.6 \%$ or $240.4 \pm 45.6 \%$ of untreated group, in thrombin-stimulated cells without or with inhibitor, respectively, mean \pm S.E.M., $\mathrm{n}=5$ ), suggesting that the possibility of the participation of $\mathrm{PAR}_{1}$ in the thrombin action is unlikely. A potent EMT inducer, TGF- $\beta(5 \mathrm{ng} / \mathrm{ml})$ showed changes similar to those with $\mathrm{PAR}_{4}$ agonists.

In accordance with our observation, such a TGF- $\beta$ induced EMT in A549 cells was also detected by previous report [22,23]. Thus, $\mathrm{PAR}_{4}$ stimulation induced EMT in alveolar epithelial cells.
Effects of inhibitors of EGF receptor kinase and Src kinase on PAR 4 -mediated EMT

PARs reportedly transactivates, i.e., phosphorylates, EGFR in a variety of cell systems such as gastric cancer cells and cardiac myocytes $[18,24]$, and phosphorylated EGFR triggers EMT in human ovarian surface epithelium [25]. Therefore, we examined whether EGFR is involved in the $\mathrm{PAR}_{4}$-mediated EMT, using an EGFR kinase inhibitor, AG1478 ( $\mathrm{Ki}$ at $3 \mathrm{nM}$ ). As shown in Figure 5A (summarized in C and D), AG1478 inhibited both of the $\mathrm{PAR}_{4}$ stimulation-induced changes in the EMT parameters (Ecadherin and $\alpha$-SMA), suggesting that EGFR signaling is involved in the $\mathrm{PAR}_{4}$-mediated EMT. Since EGFR transactivation is reportedly promoted by Src $(18,24)$, the effects of PP2 (300 nM, a Src family tyrosine kinase inhibitor) 
A E-cadherin

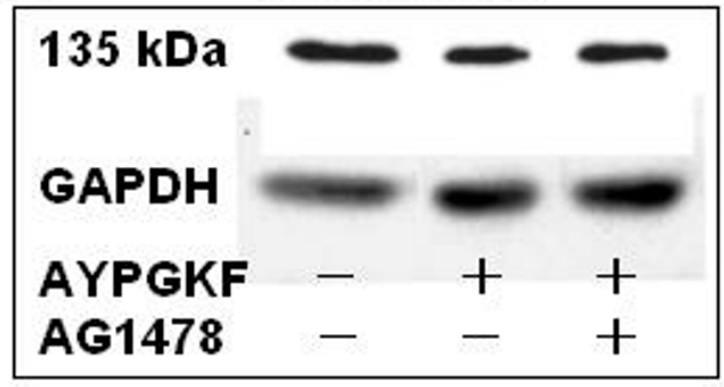

$\alpha$-SMA

\begin{tabular}{|llll|}
\hline 42 kDa & $\cdots$ & - & \\
GAPDH & & & \\
AYPGKF & - & + & + \\
AG1478 & - & - & + \\
\hline
\end{tabular}

C E-cadherin

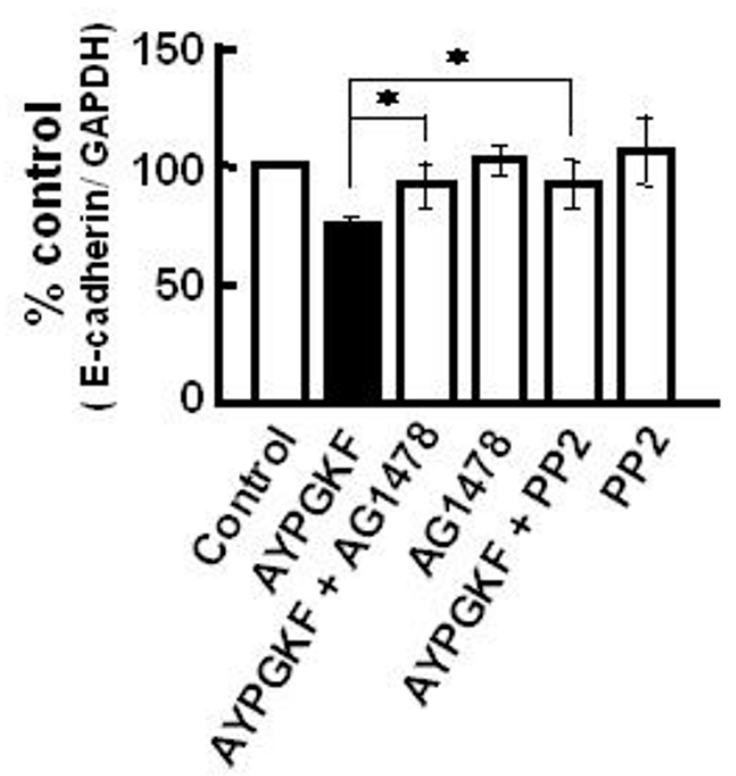

B E-cadherin

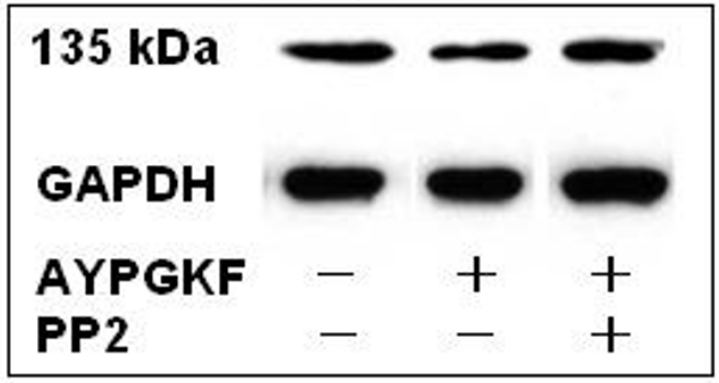

\section{$\alpha$-SMA}

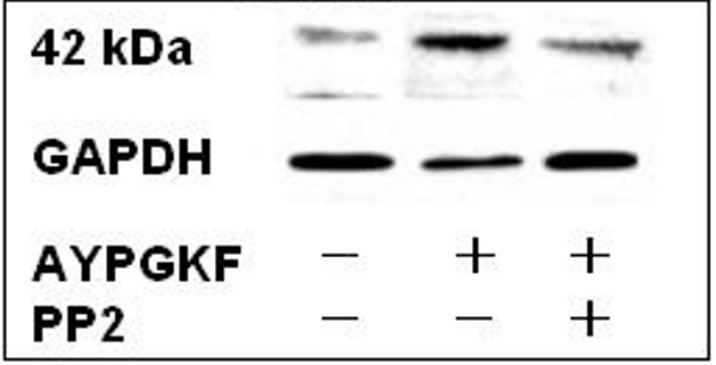

D $\alpha$-SMA

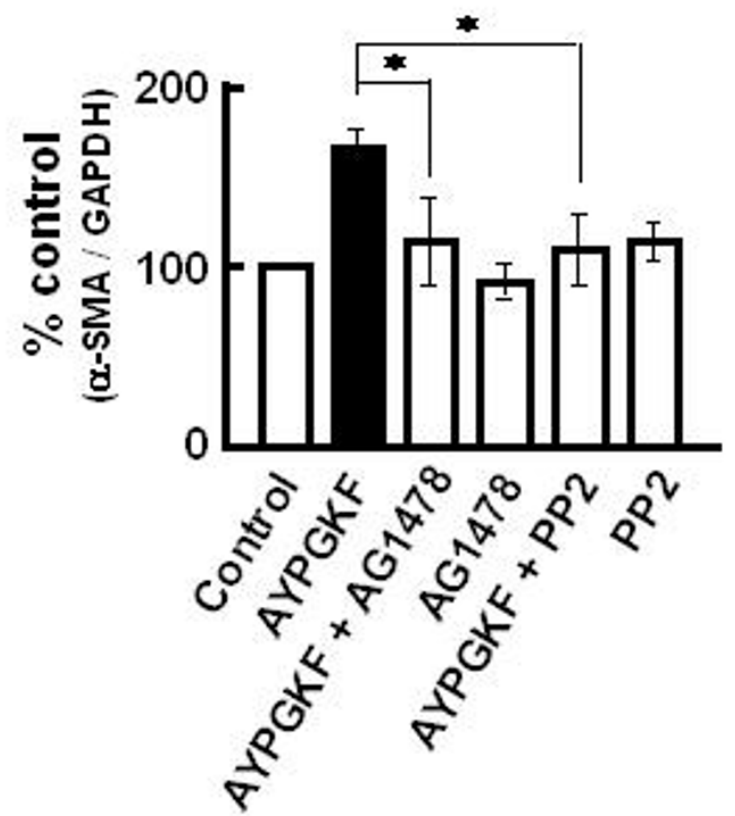

Figure 5

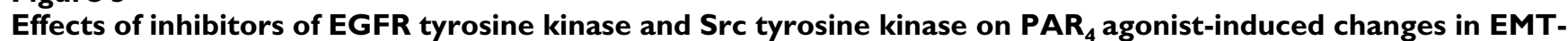
related marker protein expression in A549 cells. A549 cells were pretreatd with or without $30 \mathrm{nM} \mathrm{AG} 478$ or $300 \mathrm{nM}$ PP2 for $30 \mathrm{~min}$, and then stimulated with AYPGKF-NH $2(100 \mu \mathrm{M})$ for $96 \mathrm{~h}$ followed by immunoblotting with specific antibodies for E-cadherin, $\alpha$-SMA. (A, B) Representative Western blots for the effect of AGI478 (A) or PP2 (B) on the expression of Ecadherin and $\alpha$-SMA. (C, D) Summarized densitometric data. Each bar represents the mean \pm S.E.M. for 4-12 preparations. *P $<0.05$ compared with AYPGKF-NH $\mathrm{N}_{2}$ alone. 


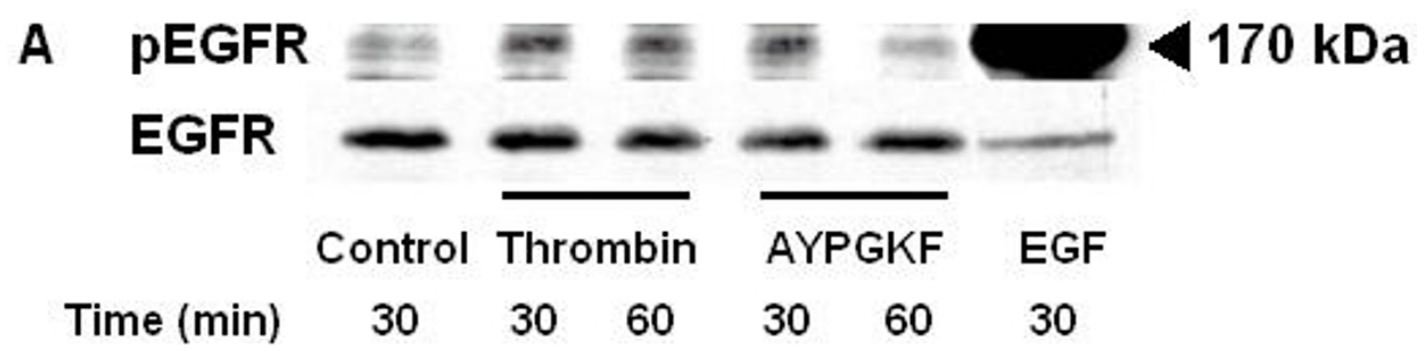

B PEGFR<smiles>[R]=[Fe]</smiles>
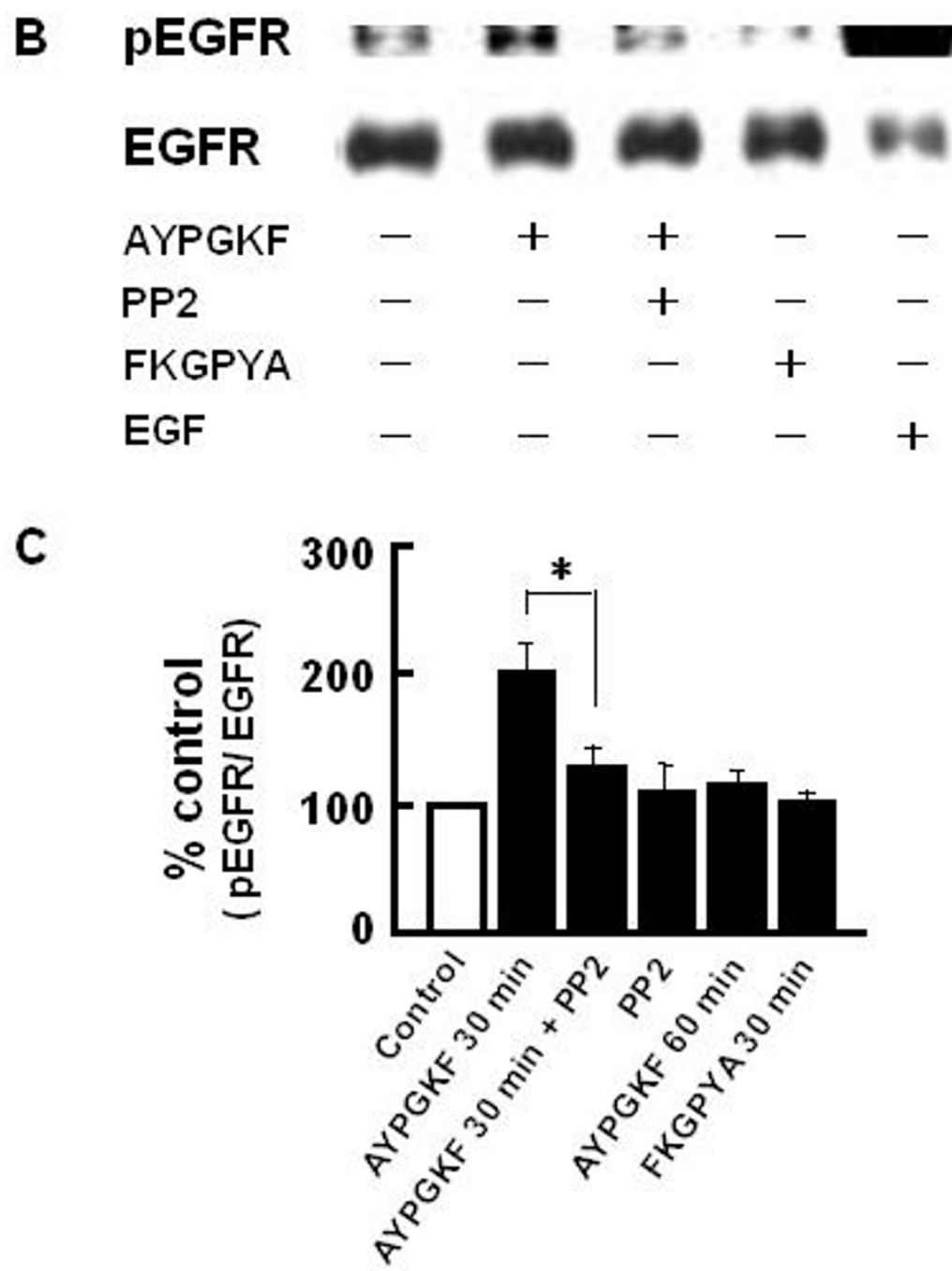

Figure 6

PAR $_{4}$ agonist-induced EGFR phosphorylation in A549 cells. A549 cells were pretreated with or without $300 \mathrm{nM} \mathrm{PP2}$ for $30 \mathrm{~min}$, and then stimulated with AYPGKF-NH $\mathrm{N}_{2}(100 \mu \mathrm{M})$ for 30-60 min followed by immunoblotting with specific antibodies for the YII 73 phosphorylated EGFR and total EGFR protein. Control; without drug treatment. (A) Representative time course of EGFR phosphorylation induced by thrombin $(\mathrm{I} \mathrm{U} / \mathrm{ml})$ or AYPGKF-NH $\mathrm{N}_{2}(\mathrm{I} 00 \mu \mathrm{M})$. As a positive control, cells were treated with EGF ( $10 \mathrm{ng} / \mathrm{ml})$ for $30 \mathrm{~min}$. (B) Representative Western blot after treatment with or without (control) various agents (AYPGKF-NH ${ }_{2}$, AYPGKF-NH $2+$ PP2, $100 \mu$ M FKGPYA-NH ${ }_{2}$ or EGF) for $30 \mathrm{~min}$. (C) Summarized densitometric data. Protein concentrations used for separation was $20 \mu \mathrm{g} / \mathrm{lane}$ (thrombin or AYPGKF-NH $\mathrm{N}_{2}$ or FKGPYA-NH $\mathrm{H}_{2}$ treated sample) or $10 \mu \mathrm{g} /$ lane (EGF treated sample). Each bar represents the mean \pm S.E.M. for 4-6 preparations. $* \mathrm{P}<0.05$ compared with AYPGKF-NH $\mathrm{H}_{2}$ alone. 


\section{A pSrc}

\section{Src}<smiles></smiles><smiles>CC1CCCO1</smiles><smiles>C#CC#CC#CCCC</smiles><smiles>CCCCOC(C)(C)C</smiles>

B

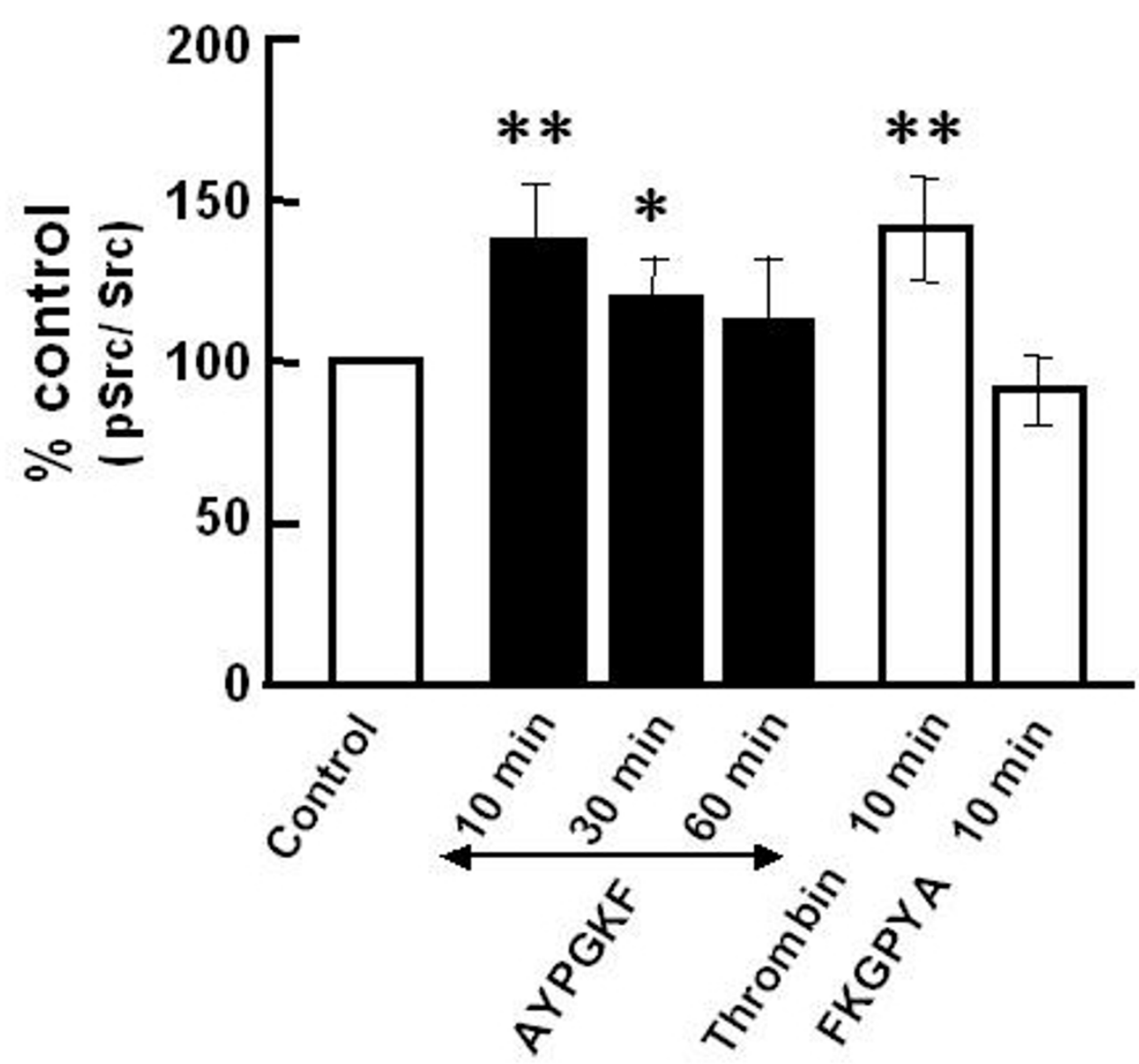

Figure 7

Western blot analyses of Src phosphorylation in A549 cells. A549 cells were treated without (control) or with AYPGKF-NH $\mathrm{N}_{2}(100 \mu \mathrm{M})$ for 10,30 or $60 \mathrm{~min}$ or with thrombin (I U/ml, $10 \mathrm{~min}$ ) or with FKGPYA-NH 2 (I00 $\mu$ M, $\left.10 \mathrm{~min}\right)$, and then subjected to immunoblotting with specific antibodies for the Y4I8 phosphorylated Src and total Src protein. (A) Representative Western blot. Stimulation time was $10 \mathrm{~min}$. (B) Summarized densitometric data. Each bar represents the mean \pm S.E.M. for 4-6 preparations. **P $<0.01$, *P $<0.05$ compared with the control. 
Control

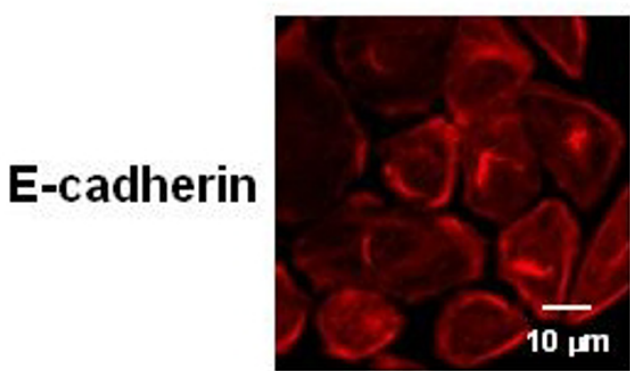

AYPGKF

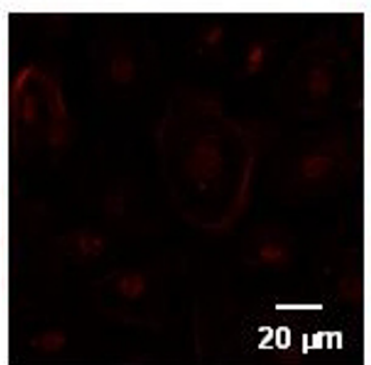

AYPGKF + AG1478

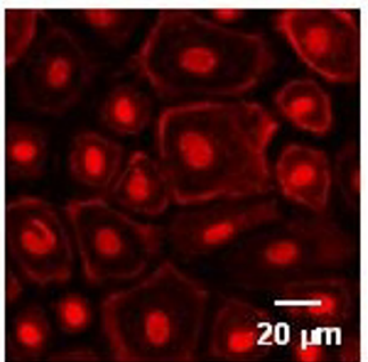

AYPGKF + PP2

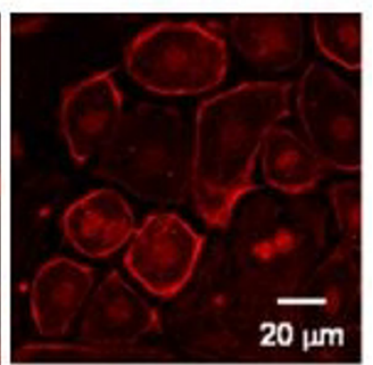

$\alpha-S M A$
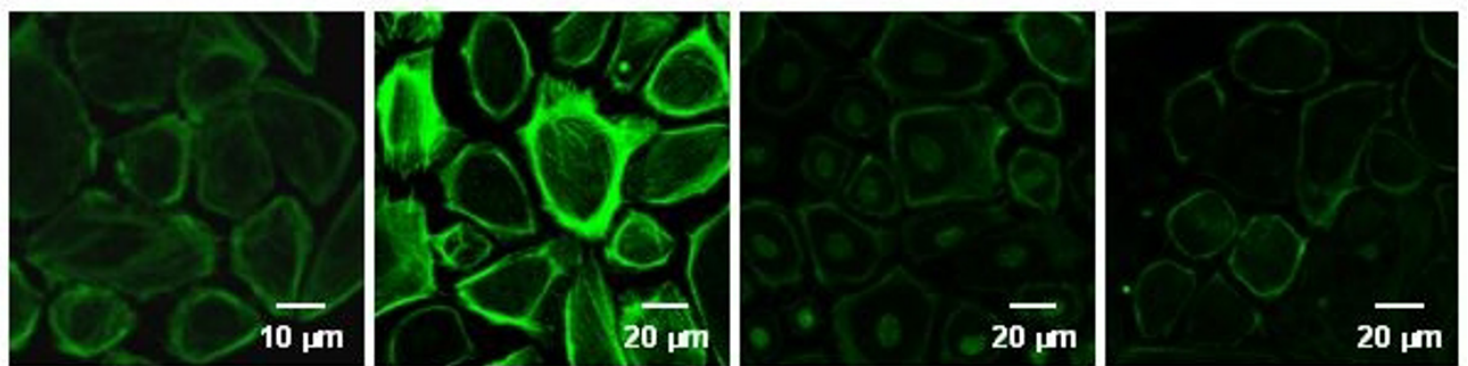

Figure 8

Effects of AG 1478 and PP2 on PAR 4 agonist induced phenotypic changes in primary cultured alveolar epithelial cells. Immunofluorescence images for a specific marker for epithelial cell (E-cadherin; rhodamine red, upper panel) or myofibroblast ( $\alpha$-SMA; FITC green, lower panel) captured with confocal lasar microscopy. Cells were treated with or without (control) AYPGKF-NH $\mathrm{NH}_{2}(\mathrm{I} 00 \mu \mathrm{M})$ for $72 \mathrm{~h}$ in the presence or absence of each inhibitor (30 nM AG I478 or $300 \mathrm{nM}$ PP2), and stained using each specific antibody as described in Method section.

were also examined. As shown in Figure 5B (summarized in $\mathrm{C}$ and D), PP2 inhibited the $\mathrm{PAR}_{4}$-mediated changes in E-cadherin and $\alpha$-SMA expression, suggesting the involvement of Src signaling in the PAR4-mediated EMT.

\section{$P_{4}$ stimulation-induced phosphorylation of EGF receptor and Src}

$\mathrm{PAR}_{4}$ stimulation induced phosphorylation of EGFR was examined. In A549 cells stimulated with thrombin (1 U/ $\mathrm{ml})$ or AYPGKF-NH $\mathrm{N}_{2}(100 \mu \mathrm{M})$ for 30 or $60 \mathrm{~min}$, tyrosine1173 phosphorylated EGFR (pEGFR) level was obviously elevated (Figure 6A and 6C). Such induction of pEGFR by $\mathrm{PAR}_{4}$ stimulation occurred as early as $30 \mathrm{~min}$ after the agonist application. EGF ( $10 \mathrm{ng} / \mathrm{ml})$ as a positive control induced a marked increase in EGFR phosphorylation. Further, this $\mathrm{PAR}_{4}$ stimulation-induced increase in pEGFR level was significantly inhibited by PP2 (Figure 6B and 6C), suggesting that Src may be an upstream signaling pathway for the $\mathrm{PAR}_{4}$ stimulation-induced EGFR transactivation. EGFR phosphorylation was not observed by the stimulation with FKGPYA- $\mathrm{NH}_{2}(100 \mu \mathrm{M})$ for $30 \mathrm{~min}$.
To test whether $\mathrm{PAR}_{4}$ stimulation activates Src, the level of Tyr416 phosphorylated Src (pSrc, activated form of Src) was measured. As shown in Figure 7, stimulation of A549 cells with $\mathrm{PAR}_{4}$-agonist peptide (AYPGKF-NH $\mathrm{H}_{2}$, but not FKGPYA- $\mathrm{NH}_{2}$, caused a rapid phosphorylation of Src. Thrombin ( $1 \mathrm{U} / \mathrm{ml}, 10 \mathrm{~min}$ ) also induced an increase in pSrc level. $\mathrm{PAR}_{4}$ stimulation thus activated Src followed by EGFR transactivation to produce EMT in lung alveolar epithelial cells.

\section{The effects of EGFR kinase and Src kinase inhibitors on} $P A R_{4}$ stimulation-induced phenotypic changes in primary cultured alveolar epithelial cells

Finally, we immunocytochemically analysed the expression of E-cadherin and $\alpha$-SMA in the primary cultured alveolar epithelial cells exposed to AYPGKF-NH $\mathrm{N}_{2}$ (100 $\mu \mathrm{M}, 72 \mathrm{~h})$ in the presence of EGFR kinase inhibitor (AG1478, $30 \mathrm{nM}$ ) or Src family tyrosine kinase inhibitor (PP2, $300 \mathrm{nM}$ ). As shown by representative fluorescence imaging data in Figure 8, pretreatment with each inhibitor for 30 min obviously reduced the $\mathrm{PAR}_{4}$ agonist peptide- 


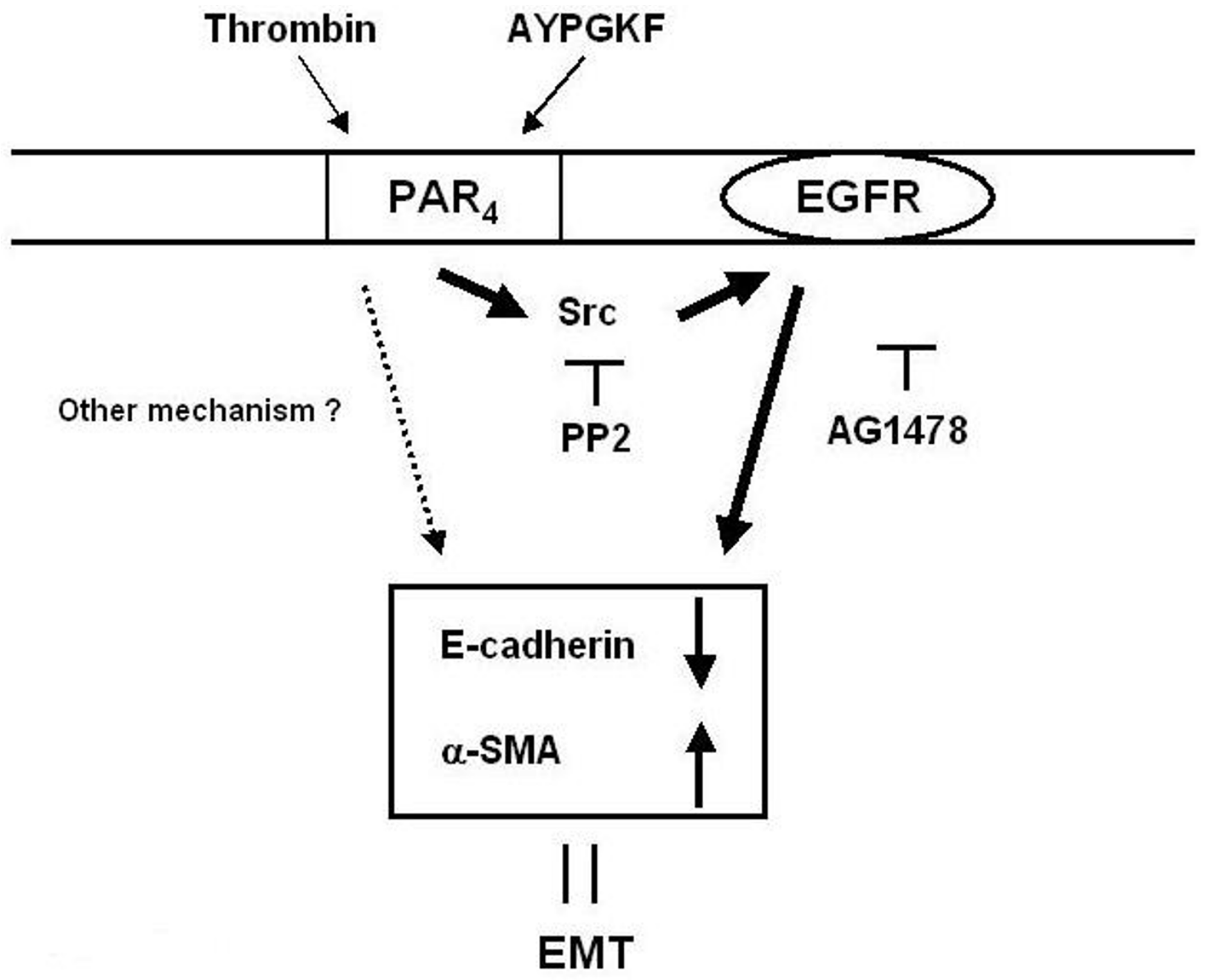

Figure 9

A schematic illustration summarizing the mechanisms for PAR -mediated EMT in alveolar epithelial cell. Bold line: a new pathway proposed in this study. Dotted line: other mechanisms.

induced EMT parameter responses (loss of cell-cell contact, decrease in expression of E-cadherin and increase in expression of $\alpha$-SMA), reinforcing the Western blot data. Each inhibitor alone unaffected cell morphology (data not shown).

\section{Discussion}

In the present study, we showed that $\mathrm{PAR}_{4}$ stimulation of alveolar epithelial cells (primary cultured mouse epithelial cells and human A549 cell line) for 72-96 h resulted in the loss of a marker for epithelial cell (E-cadherin) and induction of a marker of myofibroblast ( $\alpha$-SMA). This is the first report demonstrating that $\mathrm{PAR}_{4}$ stimulation induces EMT in the primary cultured alveolar epithelial cells. Since these phenotypic changes were inhibited by inhibitors of EGFR kinase (AG1478) or Src family tyrosine kinase (PP2), the Src/EGFR-regulated mechanism is assumed to underlie the induction of EMT.

Molecular mechanisms of EMT induction are not clarified yet. A typical EMT inducer, TGF- $\beta$ reportedly activate Smad 2 or Smad 3 signaling $[10,12]$ or Rho/ROCK signaling [25] to induce EMT. Activated Smads translocate into the nucleus and facilitate transcription of target genes, for example $\alpha$-SMA. Besides these signaling, the present findings showed new EMT-producing signaling pathway including activation of Src and EGFR.

Salient findings in this study were as follows; 1$) \mathrm{PAR}_{4}$ stimulation of alveolar epithelial cells induced morpho- 
logical change to fibroblast-like cell shape, 2) changes in EMT parameters in response to $\mathrm{PAR}_{4}$ agonist (AYPGKF$\mathrm{NH}_{2}$ ) were suppressed by inhibitors of EGFR (AG1478) and Src family (PP2) tyrosine kinases, 3) $\mathrm{PAR}_{4}$ stimulation resulted in elevation of pSrc and pEGFR levels, the latter being reduced in the presence of PP2. Based on these findings, $\mathrm{PAR}_{4}$-mediated EMT is considered to be produced through Src-mediated EGFR activation. Inhibitory effects of AG1478 or PP2 on $\mathrm{PAR}_{4}$ stimulation-induced changes in EMT parameters (Fig. 8) support our hypothesis. In line with this idea, EGF reportedly enhances TGF- $\beta$-induced EMT in human proximal tubular cells [27] and to induce EMT in human ovarian surface epithelium [25]. Further, treatment of A549 cells with EGF $(10 \mathrm{ng} / \mathrm{ml})$ for $96 \mathrm{~h}$ induced a phenotypic change as demonstrated by expression of marker proteins (E-cadherin; ${ }^{* *} 84.5 \pm 2.2 \%$, $\alpha$ SMA; ${ }^{* *} 305.5 \pm 7.4 \%$ compared to respective untreated group, mean \pm S.E.M. $\mathrm{n}=3,{ }^{* *} \mathrm{P}<0.05$, the author's unpublished data). These informations reinforce the involvement of EGFR stimulation in EMT development. As downstream signaling to induce EMT after EGFR activation, enhanced activities of PI3 kinase, Akt, ERK and/or p38 MAPK that regulate transcription of various target proteins may be plausible candidates $[25,28]$.

\section{Conclusion}

$\mathrm{PAR}_{4}$ stimulation of alveolar epithelial cells changed epithelial shape, and induced a decrease or an increase in expression of epithelial or myofibroblast marker, respectively, which is suggestive of EMT. Receptor-linked Src activation followed by EGFR transactivation was thought to be involved in this $\mathrm{PAR}_{4}$-mediated phenotypic changes in alveolar epithelial cells as summarized in Figure 9. Selective inhibition of $\mathrm{PAR}_{4}$ and/or this receptor-related signaling may yield a novel strategy to inhibit proteinasemediated development of pulmonary fibrosis.

\section{Competing interests}

The author(s) declare that they have no competing interests.

\section{Authors' contributions}

SA and HO conceived of this study, and carried out acquisition, analysis and interpretation of data, and further prepared the manuscript.

\section{YY helped Western blot experiment.}

$\mathrm{KK}$ and HA participated in the synthesis of $\mathrm{PAR}_{4}$-related peptides.

SF and CI participated in coordination of data and helped to draft the manuscript.

All authors read and approved the final manuscript.

\section{Acknowledgements}

This study was supported by grants from Kansai Medical University and Japanese Private School Promotion Foundation.

\section{References}

I. Lan RS, Stewart GA, Henry PJ: Role of protease-activated receptors in airway function: a target for therapeutic intervention? Pharmacol Ther 2002, 95:239-257.

2. Macfarlane SR, Seatter MJ, Kanke T, Hunter GD, Plevin R: Proteaseactivated receptors. Phamacol Rev 200I, 53:245-282.

3. Howell DC, Johns RH, Lasky JA, Shan B, Scotton CJ, Laurent GJ, Chambers RC: Absence of protease-activated receptor-I signaling affords protection from bleomycin-induced lung inflammation and fibrosis. Am J Pathol 2005, 166: I 353-1365.

4. Yagi $Y$, Otani $\mathrm{H}$, Ando S, Oshiro A, Kawai K, Nishikawa H, Araki H, Fukuhara S, Inagaki C: Involvement of Rho signaling in PAR2mediated regulation of neutrophil adhesion to lung epithelial cells. Eur J Pharmacol 2006, 536:19-27.

5. Hernández-Rodriguez NA, Cambrey AD, Harrison NK, Chambers RC, Gray AJ, Southcott AM, duBois RM, Black CM, Scully MF, McAnulty RJ, Laurent GJ: Role of thrombin in pulmonary fibrosis. Lancet 1995, 346: 1071-1073.

6. Kimura M, Tani K, Miyata J, Sato K, Hayashi A, Otsuka S, Urata T, Sone S: The significance of cathepsins, thrombin and aminopeptidase in diffuse interstitial lung diseases. J Med Invest 2005, 52:93-100

7. Ando S, Otani H, Yagi Y, Oshiro A, Kawai K, Araki H, Inagaki C: Protease-activated receptor 4-mediated increase in $\left[\mathrm{Ca}^{2+}\right]_{\mathrm{i}}$ in cultured mouse lung epithelial cells [abstract]. J Pharmacol Sci 2006, 100:233P.

8. Willis BC, Liebler JM, Luby-Phelps K, Nicholson AG, Crandall ED, du Bois RM, Borok Z: Induction of epithelial-mesenchymal transition in alveolar epithelial cells by transforming growth factor- $\beta I$ : potential role in idiopathic pulmonary fibrosis. $\mathrm{Am}$ Pathol 2005, 166:1321-1332.

9. Selman M, Pardo A: Role of epithelial cells in idiopathic pulmonary fibrosis: from innocent targets to serial killers. Proc Am Thorac Soc 2006, 3:364-372.

10. Zeisberg $M$, Kalluri R: The role of epithelial-to-mesenchymal transition in renal fibrosis. J Mol Med 2004, 82: I75-I8I.

II. Willis BC, duBois RM, Borok Z: Epithelial origin of myofibroblasts during fibrosis in the lung. Proc Am Thorac Soc 2006, 3:377-382.

12. Lee JM, Dedhar S, Kalluri R, Thompson EW: The epithelial-mesenchymal transition: new insights in signaling, development, and disease. J Cell Biol 2006, I 72:973-98I.

13. Winter MC, Shasby SS, Ries DR, Shasby DM: PAR2 activation interrupts E-cadherin adhesion and compromises the airway epithelial barrier: protective effect of $\beta$-agonists. Am J Physiol Lung Cell Mol Physiol 2006, 29 I:L628-635

14. Slattery C, Campbell E, McMorrow T, Ryan MP: Cyclosporine Ainduced renal fibrosis: a role for epithelial-mesenchymal transition. Am J Pathol 2005, 167:395-407.

15. Chen L, Liu BC, Zhang XL, Zhang JD, Liu H, Li MX: Influence of connective tissue growth factor antisense oligonucleotide on angiotensin II-induced epithelial mesenchymal transition in HK2 cells. Acta Pharmacol Sin 2006, 27:1029-1036.

16. Fan JM, Huang XR, Ng YY, Nikolic-Paterson DJ, Mu W, Atkins RC, Lan HY: Interleukin-I induces tubular epithelial-myofibroblast transdifferentiation through a transforming growth factor-beta I-dependent mechanism in vitro. Am J Kidney Dis 200I, 37:820-831.

17. Moffatt JD, Lever R, Page CP: Effects of inhaled thrombin receptor agonists in mice. Br J Pharmacol 2004, I 43:269-275.

18. Caruso R, Pallone F, Fina D, Gioia V, Peluso I, Caprioli F, Stolfi C, Perfetti A, Spagnoli LG, Palmieri G, MacDonald TT, Monteleone G: Protease-activated receptor-2 activation in gastric cancer cells promotes epidermal growth factor receptor trans-activation and proliferation. Am J Pathol 2006, 169:268-278.

19. Calandrella SO, Barrett KE, Keely SJ: Transactivation of the epidermal growth factor receptor mediates muscarinic stimulation of focal adhesion kinase in intestinal epithelial cells. Cell Physiol 2005, 203: 103-II0.

20. Slomlany BL, Slomlany A: Gastric mucin secretion in response to beta-adrenergic $G$ protein-coupled receptor activation is 
mediated by SRC kinase-dependent epidermal growth factor receptor transactivation. J Physiol Pharmacol 2005, 56:247-258.

21. Corti M, Brody AR, Harrison JH: Isolation and primary culture of murine alveolar type II cells. Am J Respir Cell Mol Biol 1996, | 4:309-3|5.

22. Yao HW, Xie QM, Chen JQ, Deng YM, Tang HF: TGF- $\beta$ I induces alveolar epithelial to mesenchymal transition in vitro. Life Sci 2004, 76:29-37.

23. Kasai $H$, Allen JT, Mason RM, Kamimura T, Zhang Z: TGF- $\beta$ I induces alveolarepithelial to mesenchymal cell transition (EMT). Resp Res 2005, 6:56.

24. Sabri A, Guo J, Elouardighi H, Darrow AL, Andrade-Gordon P, Steinberg SF: Mechanisms of protease-activated receptor-4 actions in cardiomyocytes. Role of Src tyrosin kinase. J Biol Chem 2003, 278: $11714-11720$.

25. Ahmed N, Maines-Bandiera S, Quinn MA, Unger WG, Dedhar S, Auersperg N: Molecular pathways regulating EGF-induced epithelio-mesenchymal transition in human ovarian syrface epithelium. Am J Physiol Cell Physiol 2006, 290: CI532-I542.

26. Masszi A, Di Ciano C, Sirokmány G, Arthur WT, Rotstein OD, Wang J, McCulloch CA, Rosivall L, Mucsi I, Kapus A: Central role for Rho in TGF- $\beta_{1}$-induced $\alpha$-smooth muscle actin expression during epithelial-mesenchymal transition. Am J Physiol Renal Physiol 2003, 284:F9II-F924.

27. Docherty NG, O'Sullivan OE, Healy DA, Murphy M, O'Neill AJ, Fitzpatrick JM, Watson RW: TGF- $\beta$ I-induced EMT can occur independently of Its proapoptotic effects and is aided by EGF receptor activation. Am J Physiol Renal Physiol 2006, 290:FI202-FI2I2.

28. Kawao N, Nagataki M, Nagasawa K, Kubo S, Cushing K, Wada T, Sekiguchi F, Ichida S, Hollenberg MD, MacNaughton WK, Nishikawa $H$, Kawabata A: Signal transduction for protease-activated receptor-2-triggered prostaglandin $E_{2}$ formation in human lung epithelial cells. J Pharmacol Exp Ther 2005, 315:576-589.

Publish with Bio Med Central and every scientist can read your work free of charge

"BioMed Central will be the most significant development for disseminating the results of biomedical research in our lifetime. "

Sir Paul Nurse, Cancer Research UK

Your research papers will be:

- available free of charge to the entire biomedical community

- peer reviewed and published immediately upon acceptance

- cited in PubMed and archived on PubMed Central

- yours - you keep the copyright

Submit your manuscript here:

http://www.biomedcentral.com/info/publishing_adv.asp
BioMedcentral 